\title{
Performance of RC Asymmetrical Building With and Without Bracings by Linear Static and Time History Research
}

\author{
Srinivasa Rao Botsa, Ravindra Vipparthy, Lakshmi Vipparthy
}

\begin{abstract}
In asymmetrical Reinforce concrete (RC) buildings, the most effective and practical method of enhancing the seismic resistance and to reduce lateral displacement of the structures by combining bracings elements in the frame. Although past studies have focussed on the modelling of bracing elements, symmetric building models in linear analysis, there have been no detailed investigation on asymmetric structures under seismic excitation. Inclined elements (bracings) react as truss web elements which would bear compression or tension stresses. In present study a $G+5$ symmetrical $R C$ bare frame, asymmetrical RC bare frame, asymmetrical $R C$ frame incurred with different types of bracings such as $X, V$, inverted $V$, eccentric forward, eccentric back bracings at outer positions in all floors. Structural members of $G+5$ frame are designed as per the provisions of Indian seismic code IS: 1893 (Part-1)-2015. It was observed that maximum reduction both in $X$ direction and $Y$-direction for $x$-type bracings in all models. It was observed that the maximum storey drift ratio of the structure under permissible limits as per the Indian seismic code IS: 1893 (Part-1)-2015 from linear static and dynamic analysis. From results obtained from linear static and dynamic analysis, the maximum forces in beams and columns reduced significantly $X$ bracings in symmetric plan and asymmetric plan model.
\end{abstract}

Index Terms-Asymmetrical building, bracings, linear static analysis, linear dynamic analysis, storey drift ratio.

\section{INTRODUCTION}

In asymmetrical buildings, the effect of wind and seismic loads will be prominent because centre of mass and centre of stiffness is not coincide all through past studies have to be used on the modelling of such frames and walls, there have been no detailed investigation of structural member failure to global failure of the structure. Conventional methods of retrofitting are used to enhance the seismic resistance of existing structures by eliminating or reducing the adverse effects of design or construction. The steel bracing system can be used for steel structures as well as concrete structures. A lack of symmetry in the plan produces torsion effects that are sometimes difficult to assess, and can be very adverse. Buildings with an asymmetric distribution of stiffness and strength in plan undergo coupled lateral and torsion motions during earthquakes. When a building is subjected to seismic excitation, horizontal inertial forces are generated in the

Revised Version Manuscript Received on 16 September, 2019.

Srinivasa Rao Botsa, Assistant Professor, Rajiv Gandhi University of Knowledge Technologies, Nuzvid. Andhra Pradesh, India.(Email: srinivasa9394258146@rguktn.ac.in)

Ravindra Vipparthy, Professor, University College of Engineering, Kakinada, Andhra Pradesh, India.(Email: ravindra.vipparthy@gmail.com)

Lakshmi Vipparthy, Professor, University College of Engineering, Kakinada, Andhra Pradesh, India. (Email: 1veerni@gmail.com) building. The resultant of these forces assumed to act through the centre of Mass (C.M) of the structure. The vertical members in the structure resist these forces and the total resultant of these systems of forces act through a point called as Centre of Stiffness (C.S). When the centre of mass and centre of stiffness does not coincide, eccentricities are developed in the buildings which further generate torsion. When the buildings are subjected to lateral loads, then phenomenon of torsional coupling occurs due to interaction between lateral loads and resistant forces. Torsional coupling generates greater damage in the buildings. Eccentricity may occur due to presence of structural irregularities. Saeed and Babak [1] suggested that the high rise buildings must be categorized based on the configuration of the structural system and value of $\mathrm{R}$ must be selected based on the configuration. Ali and Nader [2] studied the effect of midconnection detail on the behaviour of cross- bracing system. The effect of mid- connection detail of cross bracings comprised of build-up sections on the elastic- plastic behaviour of braced systems is investigated and compared with the commonly used. Buckling and post-buckling behaviour of single span- single storey models of crossbracing systems, have been studied during a linear and nonlinear static Finite Element Analysis (FEA). The analysis shows the proposed mid- connection detail can improve both strength and ductility of the cross- braced systems. Shahrzad et al. [3] carried a comparative study on different types of bracing systems in steel structures. This paper is aimed at investigating and comparing various types of bracing systems. Results shows that although diagonal bracing systems increase the energy absorption capacity of structure, but because of it's less rigidity, it leads to increasing the building weight. So in order to optimize the amount of steel consumption and obtain the light weight structure, best solution is to apply the inverted chevron bracing systems in steel frames. Siddiqi et al. [4] conducted a study on comparison of different bracing systems for tall buildings. In this research study, five different investigated bracing systems, double bracing system yielded minimum weight of structural steel. Sarita et al. [5] studied on behaviour of RC framed building with different lateral bracing systems. It was observed that the performance of the building enhanced with the provision of bracings in the framed system. It was recommended that the building with $\mathrm{X}$ - bracing at exterior 


\section{PERFORMANCE OF RC ASYMMETRICAL BUILDING WITH AND WITHOUT BRACINGS BY LINEAR STATIC AND TIME HISTORY RESEARCH}

frame in middle bays with and without bracings in the interior frame showed the best performance. J. G. Kulkarni et al. [6] conducted a research on seismic response of reinforced concrete braced frames. This paper presents the elastic seismic response of RC frames with $\mathrm{RC}$ bracing member in $\mathrm{K}$, inverted $\mathrm{A}, \mathrm{V}$ braced pattern which were analysed numerically for twelve storey building with 5 bay structures. Vani Prasad and Nivin Philip [7] found that steel bracing significantly reduces the lateral drift. Shear force and bending moment in the column at the base with respect to bare frame structure goes on increasing as $\mathrm{L} / \mathrm{B}$ ratio increases. Beka and Jong [8] proposed design procedure plan asymmetric RC frame building by matching results Nonlinear Time History (NTHA) results for six story plan asymmetric RC frame. Though past studies focussed on behaviour symmetric, asymmetric models with and without bracings, influence bracings in asymmetric models not been investigated in detail by using Time History Analysis.

\section{MODELLING AND ANALYSIS}

A six story building model located is seismic zone III from the Indian Seismic Code IS: 1893 (Part 1) [9]. The floor-to-floor height is $3.32 \mathrm{~m}$. The columns are extended to $2.06 \mathrm{~m}$ below ground level and assumed to be embedded in rock stratum. Two noded frame elements are used in the modelling of beam and column members and four node shell elements are used in floor slabs in the computer program SAP 2000 [10]. The dimensions of the plan is $23.1 \mathrm{~m}$ (longer span$\mathrm{X}$ direction) $\mathrm{x} 16.5 \mathrm{~m}$ (shorter span $-\mathrm{Y}$ direction) and height is $18.66 \mathrm{~m}$ (Z-direction). The beams and columns have same cross section $230 \mathrm{~mm}$ x $450 \mathrm{~mm}$ and $400 \mathrm{~mm}$ x $400 \mathrm{~mm}$ respectively. The thickness RC slab assumed to be $120 \mathrm{~mm}$ and bracings cross section ISA $90 \mathrm{~mm} \times 90 \mathrm{~mm} \times 7 \mathrm{~mm}$. For the rocky stratum, all possible translational and rotational degrees of freedom are restrained. The modulus of elasticity, Poisson's ratio, grade of concrete and density of concrete are $25,000 \mathrm{MPa}, 0.20, \mathrm{M} 25$ and $2500 \mathrm{~kg} / \mathrm{m} 3$ respectively. For reinforcing steel, the modulus of elasticity, Poisson's ratio and grade are 2,00,000 $\mathrm{MPa}, 0.30$ and $\mathrm{Fe} 415$ respectively.
In present study, different models named the symmetrical RC bare frame (M1) [Fig. 1], asymmetrical RC bare frame (M2) [Fig. 2] and a symmetric and symmetrical RC frame incurred with different types of bracings such as $\mathrm{X}, \mathrm{V}$, inverted $\mathrm{V}$, eccentric forward, eccentric back bracings with different types of combinations [Figs. 3-4]. These bracings were provided at outer position in straight and alternative manner.

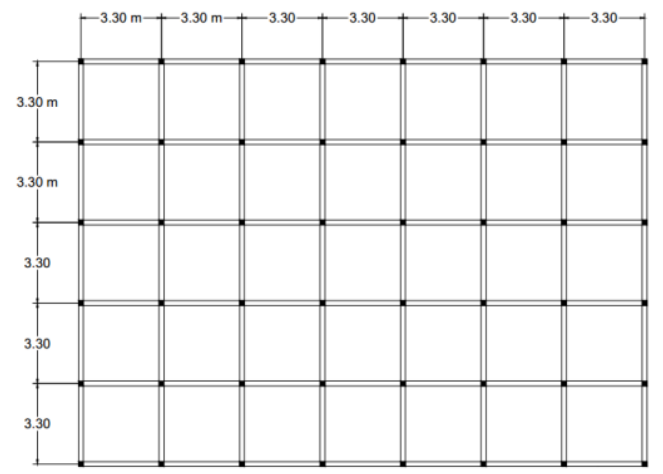

Fig. 1: Model-1 plan in X-Y plane

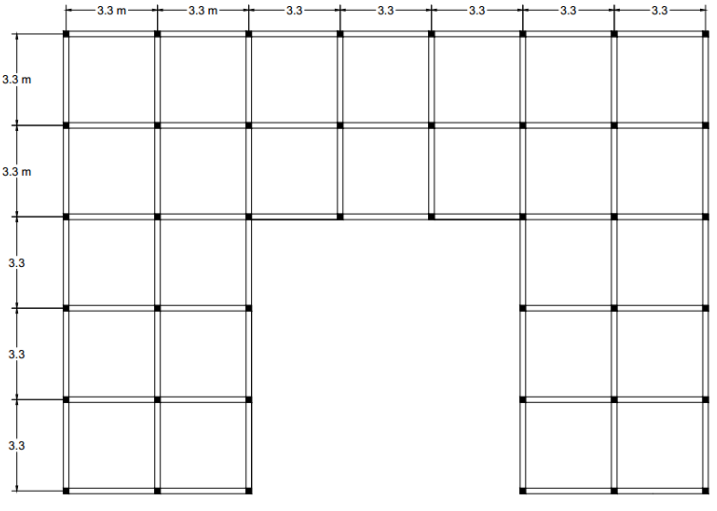

Fig.2: Model-2 Plan X-Y plane
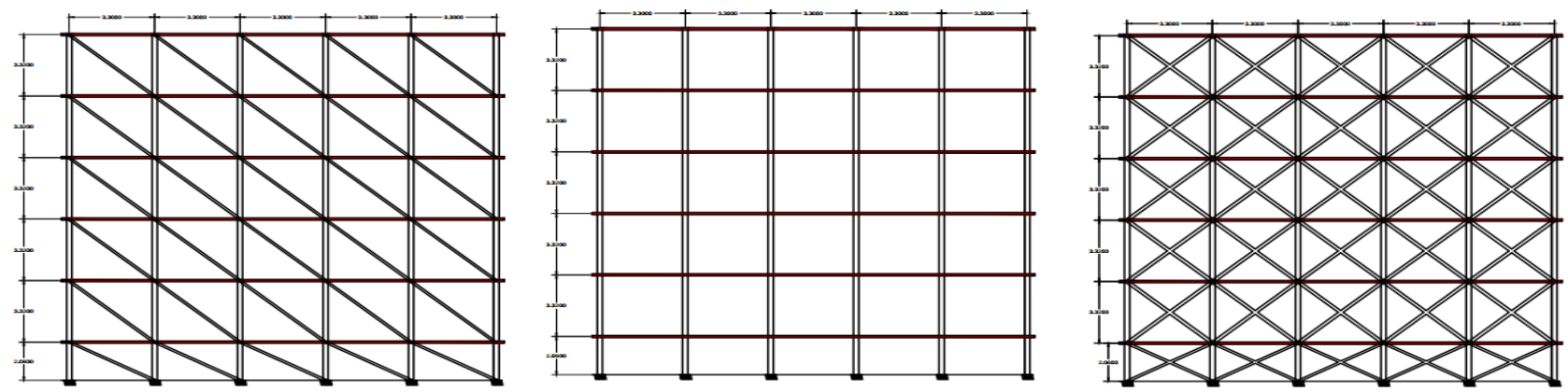

Fig 3: Model-1 (a) eccentric backward (M1-B), (b) no bracing (M1-W), (c) X- bracing (M1-X) 

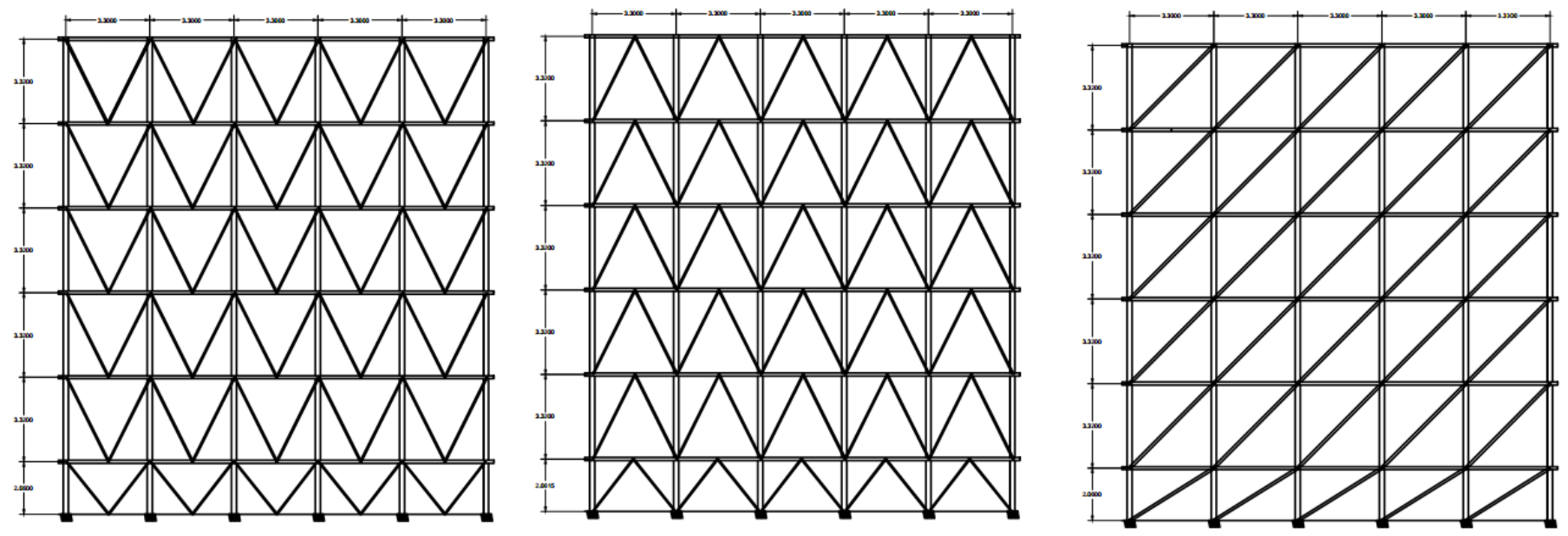

Fig 4: Model-1 (a) V Bracings (M1-V), (b) Inverted V bracing (M1-IV), (c) eccentric Forward (M1-F)

\section{TIME-HISTORY ANALYSIS:}

Time History Analysis or Dynamic Analysis is a method of structure analysis which is used to obtain the response of a structure under a specific loading or displacement varying with time. The analysis is also known as Linear Time History Analysis (LTHA). If the behaviour of the structure is in the linear elastic range during the entire course of the analysis. The appropriate ground motions have been considered from the previous available earthquakes with possible significant duration and amplitude parameters. In this study the 2001 Bhuj, 1995 Chamba Rakh, 1995 Chamba and Sikkim 2011earthquakes have been considered. The ground motion records are shown in the Fig. $5 \& 6$.

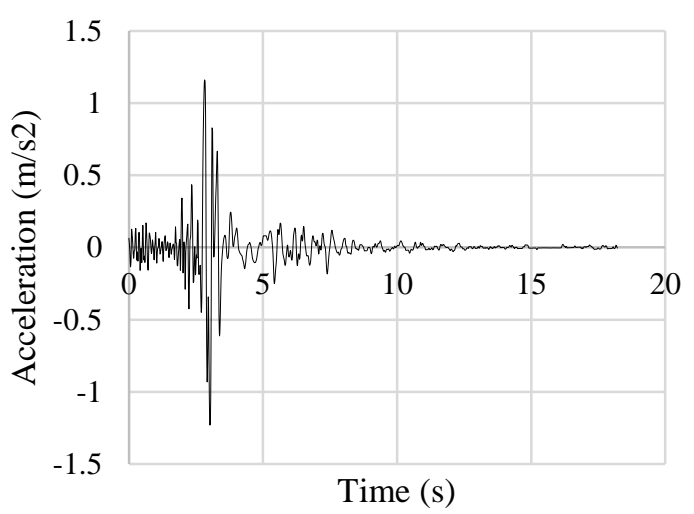

Fig. 5: Actual ground motion record at Ahmedabad station

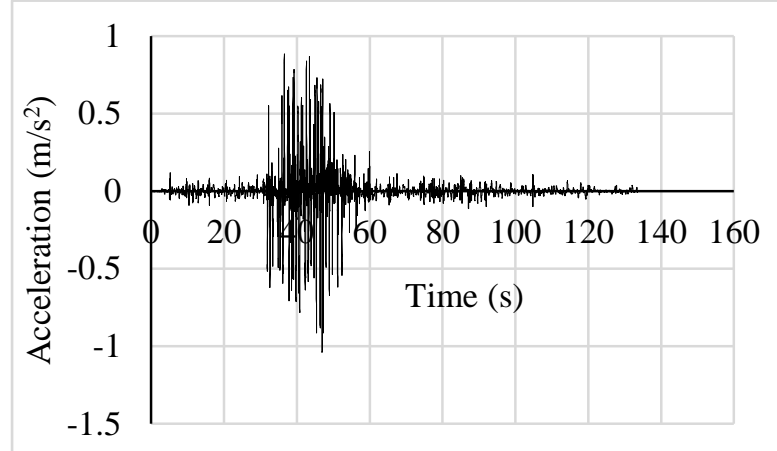

Fig. 6: Actual ground motion record at chamba station

\section{RESULTS AND DISCUSSIONS}

From linear analysis results, it was observed that there is a slight variation in storey displacement for M1 (symmetric building model) and Model 2 (asymmetric building model without bracings) in $\mathrm{X}$ and $\mathrm{Y}$ directions. Lateral displacement observed along long span direction less than shorter span direction different models (Fig. 7 and 8). There is a reduction in storey displacement along long span direction from 9.30 $\mathrm{mm}$ for Model-2 to $1.46 \mathrm{~mm}$ for the same building with $\mathrm{X}$ bracings with outer $\mathrm{X}$ - bracings in straight manner (Table 7). It was observed that, more reduction in storey displacement along short span direction from $18.48 \mathrm{~mm}$ for asymmetric building without any type of bracings to $81.73 \mathrm{~mm}$ for building with outer $\mathrm{X}$ - bracings. It was observed that, asymmetric model (M2) compared to a symmetric model (M1) observed more peak roof displacement and storey drift ratio in all type of bracings models. 


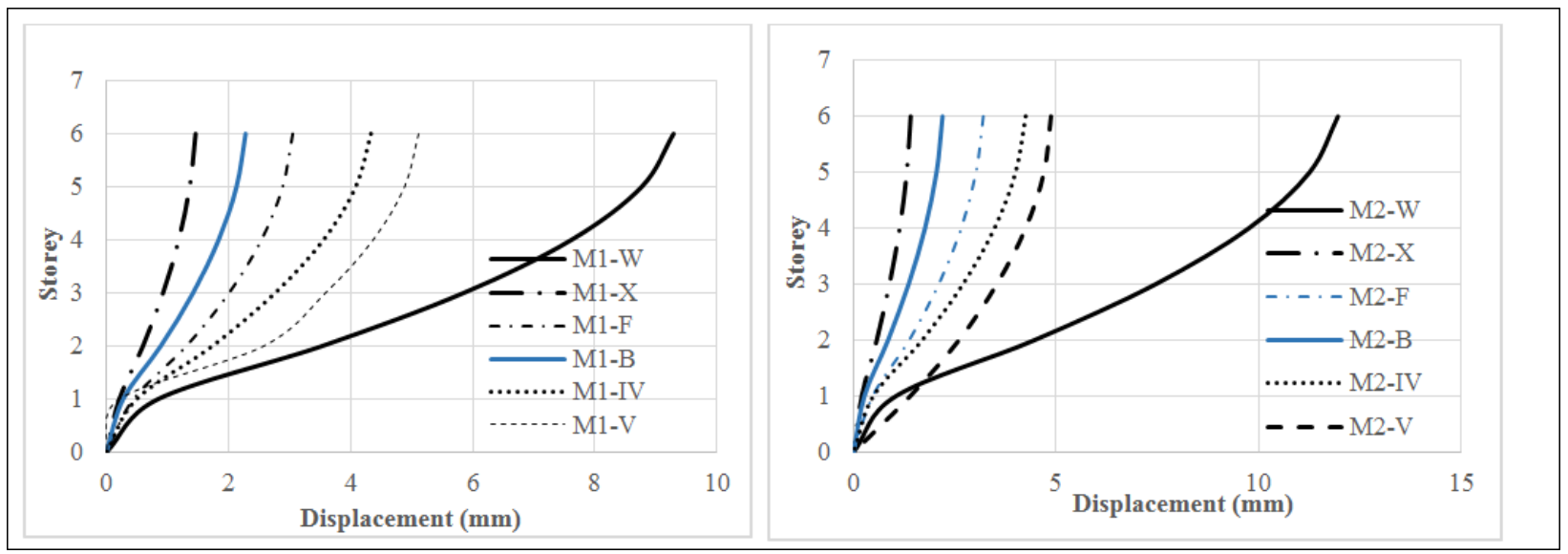

Fig. 7: Comparison of story displacement in along longer direction (a) symmetric model (M1) (b) asymmetric model (M2)

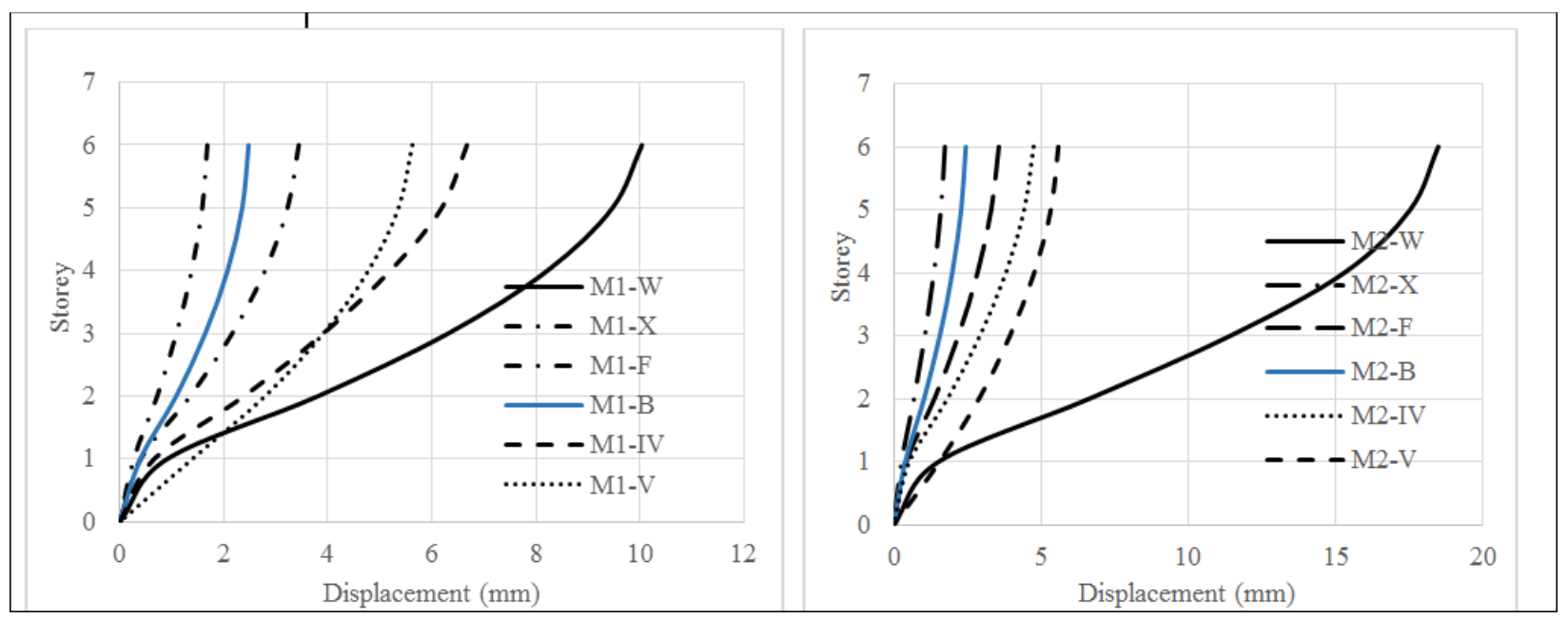

Fig. 8: Comparison of story displacement in along shorter direction (a) symmetric model (M1) (b) asymmetric model (M2)

Table 1: Peak storey displacement and story drift ration comparison in symmetric models with bracings type

\begin{tabular}{|c|c|c|c|c|c|c|c|c|}
\hline \multirow[t]{2}{*}{ Model \& Symbol } & \multicolumn{2}{|c|}{$\begin{array}{c}\text { Maximum } \\
\text { Displacement }\end{array}$} & \multicolumn{2}{|c|}{$\begin{array}{c}\text { \% reduction } \\
\text { compared } \\
\text { M1-W }\end{array}$} & \multicolumn{2}{|c|}{$\begin{array}{l}\text { Storey Drift ratio } \\
\text { (Directions) }\end{array}$} & \multicolumn{2}{|c|}{$\begin{array}{c}\% \text { reduction } \\
\text { compared to } M 1-W\end{array}$} \\
\hline & $\begin{array}{c}\mathbf{X} \\
(\mathbf{m m})\end{array}$ & $\begin{array}{c}\mathbf{Y} \\
(\mathbf{m m})\end{array}$ & $\mathbf{X}$ & $\mathbf{Y}$ & Longer $\mathbf{X}$ & Shorter Y & $\begin{array}{l}\text { Longer } \\
\mathrm{X}\end{array}$ & $\begin{array}{c}\text { Shorter } \\
\text { Y }\end{array}$ \\
\hline $\begin{array}{c}\text { Symmetric model without } \\
\text { bracing (M1-W) }\end{array}$ & 9.30 & 10.04 & -- & -- & $1.64 \times 10^{-04}$ & $1.77 \underset{-04}{X} 10$ & -- & -- \\
\hline $\begin{array}{c}\text { Symmetric model X bracing } \\
(\mathrm{M} 1-\mathrm{X})\end{array}$ & 1.46 & 1.68 & 84.27 & 83.25 & $3.00 \times 10^{-05}$ & $\underset{-05}{3.06} \mathbf{X} 10$ & 81.6 & 82.6 \\
\hline $\begin{array}{c}\text { Symmetric model Backward } \\
\text { bracing (M1-B) }\end{array}$ & 2.28 & 2.47 & 75.46 & 75.33 & $7.19 \times 10^{-05}$ & $\underset{-05}{8.28 X} 10$ & 56.1 & 53.18 \\
\hline $\begin{array}{c}\text { Symmetric model Forward } \\
\text { bracing (M1-F) }\end{array}$ & 3.05 & 3.43 & 67.15 & 65.73 & $7.79 \times 10^{-05}$ & $\underset{-04}{1.51 X} 10$ & 52.4 & 14.66 \\
\hline $\begin{array}{c}\text { Symmetric model V bracing } \\
(\mathrm{M} 1-\mathrm{V})\end{array}$ & 5.11 & 5.62 & 44.96 & 43.98 & $5.19 \times 10^{-05}$ & $\underset{-05}{6.72 \times 10}$ & 68.3 & 62.0 \\
\hline $\begin{array}{c}\text { Symmetric model Inverted V } \\
\text { bracing (M1-IV) }\end{array}$ & 4.33 & 6.67 & 53.35 & 33.52 & $4.65 \times 10^{-05}$ & $\underset{-05}{3.84 \times 10}$ & 71.5 & 78.2 \\
\hline
\end{tabular}



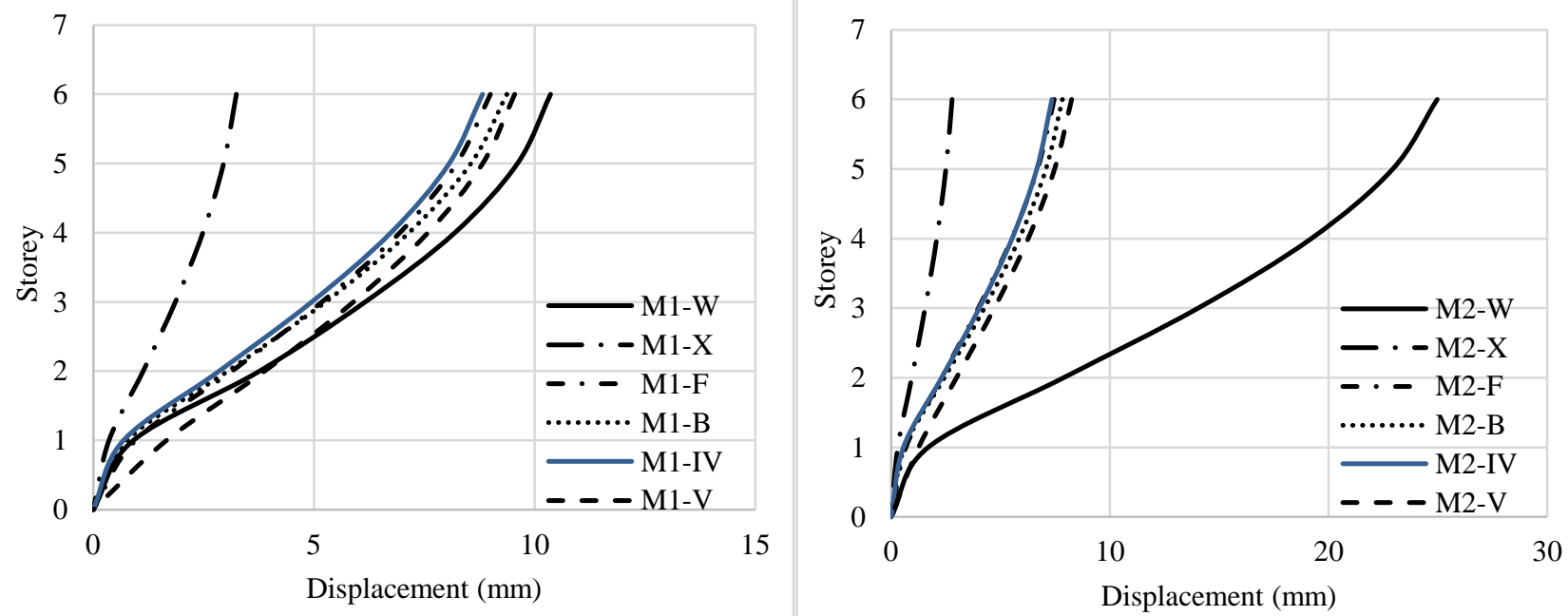

Fig. 9: Comparison of story displacement in along longer direction for Ahmedabad station (a) symmetric model (M1) (b) asymmetric model (M2)

From linear analysis results, it was observed that the storey displacement along short span and longer span directions are within elastic limit as specified in Indian seismic code IS: 1893 (Part-1)-2016 i.e. 0.004 times of the storey height is $74.64 \mathrm{~mm}$ [Figs. 7 and 8]. Lateral displacement observed along the shorter span directions are larger than those in longer span direction [Table 1\&2]. Asymmetric model (M2) observed more storey displacement in all type of models compared to symmetric model (M1) [Fig 7\&8]. In symmetric model with $\mathrm{X}$ bracings (M1-X) there is a percentage reduction in storey displacement of $84.27 \%$ and $83.25 \%$ respectively in longer span and shorter span directions [Table 7]. In asymmetric model (M2-X) there is a percentage reduction in storey displacement of $88.23 \%$ and $90.60 \%$ respectively in longer span and shorter span directions [Table 8]. From, above analysis the models with $\mathrm{X}$ bracings performed well than the models with other type bracings in symmetric and asymmetric models also. It is observed that the Storey drift ratio is high in Asymmetric model (M2) than symmetric model (M1). The reduction of storey drift in $\mathrm{M} 1-\mathrm{X}$ and $\mathrm{M} 2-\mathrm{X}$ is more than other models with bracings. Storey displacement reduction for M2-V least effective compared asymmetric model (M2) along longer and shorter span directions (Table. 2). As compared with other type of bracings in $\mathrm{V}$ and inverted observed less performance in symmetric and asymmetric models. It was observed Xbracings at outer position in straight manner can reduce storey drift by a greater amount.

Table 2: Peak storey displacement and story drift ration comparison in asymmetric model (M2) with bracings type

Fig. 9: Comparison of story displacement in along longer direction for Ahmedabad station (a) symmetric model (M1) (b) asymmetric model (M2)

From linear Time History analysis results, it was observed that the storey displacement along short span and longer span directions are within elastic limit as specified in Indian seismic code IS: 1893 (Part-1)-2002 i.e. 0.004 times of the storey height is $74.64 \mathrm{~mm}$ [Fig. 9]. Lateral displacement observed along the shorter span directions are larger than those in longer span direction [Fig. 9]. Asymmetric model (M2) observed more storey displacement in all type of models compared to symmetric model (M1) [Fig 9]. Similar trends observed in storey displacement and storey drift ratio of all models for Ahmedabad, Rakh and Chamba station actual ground motion records. In symmetric and asymmetric model (M1 \& M2) observed maximum reduction in storey displacement in $\mathrm{X}$ type bracings in longer span and shorter span directions.

Table 3: Comparison of maximum forces in frame members in symmetric model (M1) with bracings type

\begin{tabular}{|c|c|c|c|c|c|c|}
\hline FORCE & M1-W & M1-X & M1-F & M1-B & M1-IV & M1-V \\
\hline & \multicolumn{6}{|c|}{ Maximum Forces in Beams } \\
\hline Max Shear Force- $V_{\text {Max }}(k N)$ & 40.401 & 40.197 & 39.775 & 39.107 & 40.206 & 39.107 \\
\hline \multirow[t]{2}{*}{ Max Bending Moment- $\mathrm{M}_{\mathrm{Max}}(\mathrm{kN}-\mathrm{m})$} & 34.5071 & 11.3792 & 11.642 & 11.2308 & 32.3328 & 32.6464 \\
\hline & \multicolumn{6}{|c|}{ Maximum Forces in Columns } \\
\hline Max Axial Force (kN) & 861.455 & 861.863 & 861.636 & 861.636 & 861.874 & 861.554 \\
\hline Max Shear Force- $\mathbf{V}_{\text {Max }}(\mathbf{k N})$ & 38.908 & 11.877 & 17.205 & 17.205 & 23.504 & 36.78 \\
\hline Max Bending Moment-M Max $(k N-m)$ & 55.1398 & 22.3344 & 22.6335 & 22.6335 & 86.1908 & 86.3443 \\
\hline
\end{tabular}


PERFORMANCE OF RC ASYMMETRICAL BUILDING WITH AND WITHOUT BRACINGS BY LINEAR STATIC AND TIME HISTORY RESEARCH

Table 4: Comparison of maximum forces in frame members in symmetric model (M2) with bracings type

\begin{tabular}{|c|c|c|c|c|c|c|}
\hline FORCE & M2-W & M2-X & M2-F & M2-B & M2-IV & M2-V \\
\hline & \multicolumn{6}{|c|}{ Maximum Forces in Beams } \\
\hline Max Shear Force- $V_{\text {Max }}(k N)$ & 59.39 & 42.802 & 42.33 & 41.213 & 42.33 & 42.802 \\
\hline \multirow[t]{2}{*}{ Max Bending Moment-M $M_{\text {Max }}(k N-m)$} & 75.1219 & 13.1697 & 13.7 & 13.1583 & 29.0627 & 39.5395 \\
\hline & \multicolumn{6}{|c|}{ Maximum Forces in Columns } \\
\hline Max Axial Force (kN) & 819.33 & 800.468 & 803.868 & 816.196 & 808.649 & 806.456 \\
\hline Max Shear Force- $V_{\text {Max }}(k N)$ & 42.538 & 10.982 & 16.241 & 20.807 & 21.005 & $\mathbf{7 5 . 7 9 5}$ \\
\hline Max Bending Moment-M $M_{\text {Max }}(k N-m)$ & 85.3019 & 22.6023 & 19.9301 & 25.9554 & 27.7831 & 94.7207 \\
\hline
\end{tabular}

From the comparison of maximum bending moment and shear forces across the models. It is observed that maximum bending moments $\left(\mathrm{M}_{\mathrm{Max}}\right)$ and shear forces $\left(\mathrm{V}_{\mathrm{Max}}\right)$ in asymmetric model (M2-W) more than symmetric model (M1-W). It is also observed that models with bracings observed that less bending moment in beams compared to model without bracings in symmetric and asymmetric models due to lateral force observed by the bracings. Bracings reduces maximum shear force and bending moments in columns compared models without bracings. Symmetric model with X (M1-X) bracings observed reduction of 67.04 $\%$ in maximum bending moments in beams compared to symmetric model without bracing (M1-W). Asymmetric model (M2-X) observed maximum reduction $74.18 \%$ in maximum Shear force $\left(\mathrm{V}_{\max }\right)$ and $73.15 \%$ in maximum bending moments $\left(\mathrm{M}_{\max }\right)$ compared to asymmetric model without bracing (M2-W) due to large portion lateral force observed by the $\mathrm{X}$ bracings. In similar behaviour observed in the Linear Time history analysis for symmetric models and asymmetric models with $\mathrm{X}$ bracings.

\section{CONCLUSIONS}

$>$ From linear static and dynamic analysis, peak storey displacement along shorter and longer span directions are within elastic limit as specified in Indian seismic code IS-1893 (Part-1)-2016 i.e. 0.004 times of the storey height.

$>$ In models, peak lateral displacement and storey drift ratio observed maximum in shorter span directions compared to longer span in symmetric model and asymmetric model from linear static and dynamic analysis.

$>$ From linear analysis, the percentage reduction in storey displacement of $82-85 \%$ in symmetric models with $\mathrm{x}$ bracings (M1-X) compared symmetric model without bracings (M1-W)

$>$ Peak storey displacement observed 20-40 \% in asymmetric model (M2-W) more compared to symmetric model (M1-W) due plan irregularity.

$>$ From linear static analysis, the percentage reduction in storey displacement of $87-91 \%$ in asymmetric model with $\mathrm{x}$ bracings (M2-X) compared asymmetric model without bracings (M2-W).

$>$ From linear static analysis, maximum reduction in storey drift ratio of 85-86 \% observed in asymmetric model with bracings (M2-X) compared to asymmetric model without bracings (M2-W) in X and Y directions.

$>$ From linear static and dynamic analysis, Bracings reduces maximum shear force and bending moments in columns compared models without bracings.
$>$ In columns, asymmetric model (M2-X) observed maximum reduction $74.18 \%$ in maximum Shear force $\left(\mathrm{V}_{\max }\right)$ and $73.15 \%$ in maximum bending moments $\left(\mathrm{M}_{\max }\right)$ compared to asymmetric model without bracing (M2-W) due to $\mathrm{X}$ bracings.

From linear time history analysis, it was observed that same peak storey displacements trends and storey drift ratios like linear static analysis.

\section{REFERENCES}

1. Saeed, R. and Babak, H.M. (2014), 'X-Bracing Configuration and seismic response', World Academy of Science, Engineering and Technology, International Journal of Civil, Architectural, Structural and Construction Engineering, Vol.8, No.6, pp. 628-632.

2. Ali, D. and Nader, H. (2009), 'Effect of mid-connection detail on the behavior of x-bracing systems', Journal of Construction Steel Research, Vol. 65, No. 4, pp. 985-990.

3. Shahrzad, E., Danesh, N. and Khosrow, B. (2011) 'Comparative Study on Different Types of Bracing Systems in Steel Structures', World Academy of Science, Engineering and Technology, Vol.73, pp. 1863-1867.

4. Siddiqi, Z.A., Rashid, H. and Usman, A. (2014): "Comparison of Different Bracing Systems for Tall Buildings", Pakistan. Journal of Engineering and Applied Sciences, Vol. 14, pp. 17-26.

5. Sarita, S., Megha, K., Rahul, K. and Taranjeet, K. (2012), 'Behavior of RC framed building with different lateral bracing systems", Proceedings of International conference on Adavances in Civil Engineering 2012, New Delhi, India, pp. 151-155.

6. Kulkarni, J. G., Kore, P. N. and Tanawade, S. B. (2013), 'Seismic response of reinforced concrete braced frames', International Journal of Engineering Research and Applications, Vol. 3, No. 4, pp.1047- 1053.

7. Vani Prasad and Nivin Philip (2014), 'Effectiveness of inclusion of steel bracing in existing RC framed structure', International Journal of Research in Engineering \& Technology, Vol. 2, No. 9, pp. 81-88.

8. Beka Hailu Abele and Jong She Lee (2019), 'Accounting for torsional response in direct displacement based design of plan asymmentric reinforced concete frame buildings' KSCE Journal of Civil Engineering, Vol 23, No.4, pp. 1190-1206.

9. Bureau of Indian Standards (BIS). 2016. "Criteria for Earthquake Resistant Design of Structures - Part1: General Provisions and Buildings.” IS 1893 (Part 1): 2016, BIS, New Delhi, India. 
10. Computers and Structures Inc. (CSI). 2012. SAP2000 program manual, Berkeley, USA.

11. Bureau of Indian Standards (BIS). 2000. "Plain and Reinforced Concrete - Code of Practice.” IS 456: 2000 , Fourth Revision, BIS, New Delhi, India.

12. Bureau of Indian Standards (BIS). 2003. "Indian Standard code of practice for design loads (other than earthquake) for buildings and structures, Imposed loads." IS 875 (Part 2): 1987, Second Revision, BIS, New Delhi, India.

13. Bureau of Indian Standards (BIS). 2015. "Indian Standard code of practice for design loads (other than earthquake) for buildings and structures, Wind loads." IS 875 (Part 3): 2015, Third Revision, BIS, New Delhi, India. 